\author{
Article \\ Doi 10.5943/mycosphere/8/8/7 \\ Copyright $\odot$ Guizhou Academy of Agricultural Sciences
}

\title{
Russula brunneopurpurea sp. nov. and its ectomycorrhiza from Pakistan
}

\author{
Jabeen $\mathrm{S}^{1, *}$, Niazi $A R^{2}$ and Khalid $A N^{2}$ \\ ${ }^{1}$ University of Education, Faisalabad Campus, Samanabad, Faisalabad, Pakistan \\ ${ }^{2}$ Department of Botany, University of the Punjab, Quaid-e-Azam Campus-54590, Lahore, Pakistan \\ *Correspondence to: sanajabeenue@gmail.com,ectomycorrhizae@gmail.com
}

Jabeen S, Niazi AR, Khalid AN 2017 - Russula brunneopurpurea sp. nov. and its ectomycorrhiza from Pakistan. Mycosphere 8(8), 1059-1069, Doi 10.5943/mycosphere/8/8/7

\begin{abstract}
Russula brunneopurpurea sp. nov. and its ectomycorrhiza were collected from different coniferous forests of district Swat, Pakistan. Basidiomata and ectomycorrhizal morphotypes are described and illustrated. Morphologically, it is characterized by its purple to brownish-purple shades of the pileus, sometimes cream tinge at the centre or towards the edges; off-white to cream or yellowish hymenium with few lamellulae; amyloid, subglobose $(8.7-9.9 \times 7.3-8.2 \mu \mathrm{m})$ basidiospores having prominent warts without reticulum; fusiform, mucronate to rostrate hymenal cystidia and subulate pileocystidia. Its ectomycorrhiza is characterized by irregular to monopodial pinnate or monopodial pyramidal morphotypes; plectenchymatous mantle layers; emanating hyphae bearing simple septa; lageniform cystidia on the outer mantle surface and loosely arranged, intermingled rhizomorphs hyphae. Combination of all these characters and molecular phylogenetic analysis of internal transcribed spacer sequences of nuclear ribosomal DNA confirmed its identity as a new species in Russula section Tenellae.
\end{abstract}

Key words - Cedrus deodara, ITS, Russulaceae, taxonomy

\section{Introduction}

Russula Pers. is a large monophyletic genus of agaricoid fungi that forms ectomycorrhizal association with diverse groups of plants (Miller \& Buyck 2002, Larsson \& Larsson 2003, Buyck et al. 2008, 2010). The genus is characterized by ornamented amyloid basidiospores, brittle context and absence of lactiferous tissue. Europe is considered to be the species rich region in terms of systematic taxonomic literature (Romagnesi 1967a, 1985, Sarnari 2005). From Asian countries, the data is being generated rapidly since last few years. Representatives of Russula from Asia have been published by several workers (Das et al. 2006, 2010, 2014, Manimohan \& Latha 2011, Li et al. 2013, 2015, 2016, Park et al. 2014, Razaq et al. 2014, Jabeen et al. 2015, 2016, Saba \& Khalid 2015, Dutta et al. 2015, Khatua et al. 2015, Paloi et al. 2015, Zhao et al. 2015). From Pakistan, so far 27 species of Russula have been reported (Ahmad et al. 1997, Niazi et al. 2006, Niazi 2008, Razaq et al. 2014, Jabeen et al. 2015, 2016, Saba \& Khalid 2015).

During the field surveys for the collection of ectomycorrhizal fungi, several specimens of Russula brunneopurpurea sp. nov. were collected, these specimens seem close to R. amethystina Quél. and allies. Ectomycorrhizal morphotypes collected from different regions of Pakistan were collected and analyzed to study ectomycorrhizal fungal communities associated with Himalayan 
cedar. While analyzing the sequences from ectomycorrhizae, a sequence found close to this group. Molecular phylogenetic analysis of internal transcribed spacer (ITS) from nuclear ribosomal DNA and macro-morphological and anatomical characters revealed the identity of these specimens as a new taxon and placed in Russula section Tenellae Quél. which is characterized by small basidiomata with a context that becomes yellow or yellow-brown on bruising, formed a solid recognizable group in phylogenetic tree with a number of recognizable subsections (Miller \& Buyck 2002).

\section{Materials \& Methods}

\section{Sampling site description}

Samples were collected from Kalam and Mashkun; two different localities in Swat district, Khyber Pakhtunkhwa, Pakistan. These areas are occupied by offshoots of Hindu Kush mountains (Hamayun 2003) and the forests are typically dry and temperate (Stucki \& Khan 1999) and dominated by Cedrus deodara (Roxb. ex D. Don) G. Don along with Pinus spp. and Quercus oblongata D. Don (Champion et al. 1965). These areas remain under snow cover during winter and receive $3310 \mathrm{~mm}$ mean annual snowfall, while July and August are the hottest months of the year. Rain is received in large amounts during March and April. The summer and autumn are relatively dry seasons. Mean annual rainfall is $500 \mathrm{~mm}$. Mean annual maximum and minimum temperatures are $17^{\circ} \mathrm{C}$ and $4^{\circ} \mathrm{C}$, respectively (Champion et al. 1965; Stucki \& Khan 1999).

\section{Morphological study of basidiomata}

Specimens were photographed using Nikon D70S digital camera. Morphological features of fresh basidiomata were recorded and colours were designated using Munsell Colour System (1975). The specimens were dried in hot air using electric fan heater for long term preservation. For detailed anatomical descriptions; tissues from different parts of the basidiomata were mounted. Phloxine was used for better contrast and $\mathrm{KOH}(5 \%)$ was used to observe coloured hyphae. Anatomical features were noted under microscope (MX4300H, Meiji Techno Co., Ltd., Japan). Measurements were recorded using Carl Zeiss Jena ocular micrometer and line drawings were made using LEITZ Wetzlar Camera Lucida.

The abbreviation $[n / l / p]$ indicates $n$ basidiospores measured from $l$ basidiomata of $p$ collections. Dimensions for basidiospores are given as length $\times$ width $(1 \times w)$. Extreme values are given in parenthesis. Q indicates $1 / \mathrm{w}$ ratio of the spore and avQ means average $\mathrm{Q}$ of all spores $(\mathrm{Ge}$ et al. 2010). Voucher specimens were deposited in LAH Herbarium, Department of Botany, University of the Punjab, Quaid-e-Campus, Lahore Pakistan. Sequences generated during this study were deposited in GenBank.

\section{Morphological study of ectomycorrhiza}

Soil blocks of $15 \mathrm{~cm}^{3}$ were dug a few centimeters away from tree trunks with care to ensure that the fine roots in the soil block belonged to the selected tree species. Twenty soil cores were taken from each sampling site. In laboratory, each soil core was soaked in water for few hours to loosen the adhering soil particles and then put on a $2 \mathrm{~mm}$ sieve under running water to separate the roots from the soil. The ectomycorrhizal roots were isolated under incandescent light and carefully sorted out into morphotypes under a Meiji Techno EMZ-5TR stereomicroscope. The morphotypes were cleaned under the stereomicroscope using a fine brush. Morphologically, identical morphotypes were kept in McCartney bottles in distilled water for later examination. Replicates of these morphotypes were kept at $8^{\circ} \mathrm{C}$ in eppendorf tubes containing $1 \mathrm{ml}$ of $2 \%$ CTAB buffer for molecular analysis. Morphological characters were noted under the stereomicroscope. For anatomical details, mantle layers (inner and outer) and radiating hyphae were mounted in trypan blue stain (Agerer 1991). Hyphae were measured using an ocular micrometer and drawn using a camera lucida. 


\section{Molecular phylogenetic studies}

For genomic DNA extraction, CTAB method (Bruns 1995) was followed. Internal Transcribed Spacer (ITS) regions along with central 5.8S region of nuclear ribosomal DNA (nrDNA) were amplified (Gardes \& Bruns 1993) using forward primer ITS1F (5'CTTGGTCATTTAGAGGAAGT-3') and reverse primer ITS4B (5' TCCTCCGCTTATTGATATGC-3') (White et al. 1990). The PCR products were sent to Macrogen Inc. (Korea) for sequencing.

For phylogenetic analysis, consensus sequence generated from the sequences obtained by both primers in BioEdit version 7.2.5 (Hall 1999). Sequences with closest match at NCBI (http://www.ncbi.nlm.nih.gov/) were selected from GenBank to reconstruct phylogeny. The sequences with less query cover and negative $\mathrm{E}$ value were left aside. Published sequences of the closest relatives of the species were also included in the final data set. Boletus reticuloceps (M. Zang, M. S. Yuan \& M. Q. Gong) Q. B. Wang \& Y. J. Yao (EU231968) was chosen as out group (Shimono et al. 2004). Multiple sequences were aligned using online MUSCLE by EMBL-EBI, Wellcome Trust Genome Campus, UK (http://www.ebi.ac.uk/Tools/msa/muscle/). For phylogenetic study of ITS sequences, Maximum likelihood (ML) analysis was performed using Jukes-Cantor model (Jukes \& Cantor 1969) in MEGA 6.0 software (Tamura et al. 2013) to test the phylogeny at 1000 bootstraps. Percentage identity and divergence in nrDNA-ITS of the taxa were analysed using MegAlign (DNA Star, Inc.). Sequences generated in this study were submitted to GenBank he methods should be adequately detailed or referenced to other work.

\section{Results}

\section{Phylogenetic analysis}

Sequencing of the PCR products from the DNA of Russula brunneopurpurea sp. nov. using ITS1F and ITS4 primers yielded $722-847$ base pairs. A 625 base pair consensus sequence was obtained by trimming the motifs. BLAST searched revealed its $98-99 \%$ identity with $R$. amethystina (JF908682) from Italy, $R$. gilva Zvára (KF002762) from China, $R$. lutea (Huds.) Gray (HQ604848 and KF679818) from Pakistan and $R$. postiana Romell (KF850410 and AF230898) from Spain with $98-100 \%$ query cover and $0.0 \mathrm{E}$ value.

The phylogenetic analysis revealed five major clades representing sections within the genus (Fig 1). These clades correspond to the phylograms in previous studies based on morphological characters (Miller \& Buyck 2002, Li et al. 2015, 2016). Sequences generated from local basidiomata and ectomycorrhizal tissue clustered with $R$. amethystina (JF908682) from Italy, $R$. lutea (KF679818) generated from root tip from Pakistan and a sequence (AF230998) from Spanish basidiome in section Tenellae with strong bootstrap support. Russula amethystina sequences do not form a monophyletic cluster in the phylogram. The sequence from the type specimen of $R$. amethystina and other related taxa formed a separate lineage from the sequences generated during this study ( $\mathrm{Li}$ et al. 2016).

\section{Taxonomy}

Russula brunneopurpurea S. Jabeen \& A. N. Khalid, sp. nov.

Figs $2-3$

MycoBank number: MB 820971

Etymology - referring to the brownish purple color of the pileus.

Diagnosis - Purple to brownish-purple shades of the pileus with sometimes cream tinge at the centre or towards the edges; off-white to cream or yellowish hymenium with few lamellulae; amyloid, subglobose $(8.7-9.9 \times 7.3-8.2 \mu \mathrm{m})$ basidiospores having prominent warts on the surface without reticulum; fusiform, mucronate to rostrate hymenal cystidia and subulate pileocystidia.

Holotype - Pakistan, Khyber Pakhtunkhwa province, Malakand division, Swat district, Kalam, $2400 \mathrm{~m}$ asl, on soil under Cedrus deodara, 4 Sep 2013, S. Jabeen \& A. N. Khalid K2-11; SJ29 (LAH35058; GenBank KT953613). 


\section{Morphological description}

Pileus 3-7 cm broad, campanulate when young becoming convex to infundibuliform at maturity; purple $2.5 \mathrm{R} 2 / 6$ to brownish purple (5RY/6) or reddish violet $(5 \mathrm{R} 4 / 12)$, sometimes cream $(2.5 \mathrm{Y} 8 / 6)$ at the centre or edges; surface smooth, dry; margins smooth, incurved when young, becoming straight to uplifted at maturity. Lamellae up to $0.35 \mathrm{~cm}$ broad, creamy white $(2.5 \mathrm{Y} 9 / 2)$ to yellowish (2.5Y8/6) or brownish (7.5YR5/6) when dry; regular, adnexed, subdistant to close, edges entire. Lamellulae few. Stipe 3-7 cm $\times 0.7-1.9 \mathrm{~cm}$, central, clavate, surface smooth to longitudinally striate, bare, white to cream $(5 Y 9 / 2)$.

Basidiospores [60/6/6] (8.2) 8.7-9.9 (10.4) × (6.0) 7.3-8.2 (8.7) $\mu \mathrm{m}, \mathrm{Q}=(1.0) 1.05-1.35$ (1.41), avQ = 1.21; subglobose, ornamented, prominent sharp-prickly warts accompanied with some low isolated warts, apiculus prominent, pale yellow in $5 \% \mathrm{KOH}$, amyloid in Malzer's reagent. Basidia (41.3) 46.6-48.9 (52.1) × (9.7) 10.6-12.7 (12.6) $\mu \mathrm{m}$, clavate, guttulate, thinwalled, wall up to $3 \mu \mathrm{m}$ thick, pale yellow to hyaline in $5 \% \mathrm{KOH}$. Cheilocystidia (43.2) 49.6-57.3 $(71.1) \times(7.4) 8.9-10.1(11.5) \mu \mathrm{m}$, fusiform, mucronate to rostrate, guttulate, pale yellow to hyaline in 5\% KOH. Pleurocystidia (57.3) 59.1-68.2 (72.7) $\times(7.2) 7.8-9.0$ (11.8) $\mu \mathrm{m}$, variable in shape, from fusiform, mucronate to rostrate, pale yellow to hyaline in $5 \% \mathrm{KOH}$. Pileipellis hyphae (5.45) 8.18-11.7 (15.4) $\mu \mathrm{m}$ wide, filamentous, branched, pale yellow to hyaline in $5 \% \mathrm{KOH}$, septa infrequent, pileocystidia $(12.3-20.3 \times 2.1-3.5 \mu \mathrm{m})$, frequent, subulate. Stipitipellis hyphae (6.36) 8.18-12.7 (14.5), filamentous, branched, pale yellow to hyaline, in $5 \% \mathrm{KOH}$, rarely septate, clamp connections not observed.

Additional material examined - Pakistan, Khyber Pakhtunkhwa province, Malakand division, Swat district, Kalam, $2400 \mathrm{~m}$ asl, on soil under Cedrus deodara, 3 Sep 2013, S. Jabeen and A. Ishaq K7; SJ18 (LAH35057; GenBank KT953612); Mashkun, $2500 \mathrm{~m}$ asl, on soil under $C$. deodara, 5 Sep 2013, S. Jabeen \& A. N. Khalid K4-27; SJ25 (LAH35059); S. Jabeen and A. N. Khalid K4-12; SJ84 (LAH35060; GenBank KT953615); K4-28; SJ31 (LAH35061); K4-29; SJ22 (LAH35062); K4-25; SJ59 (GenBank KT953614); MT2-E; SJ92 (LAH35063; GenBank KT953616); MT2-1 (LAH35064).

\section{Morphological characterization of ectomycorrhiza}

Fig 4

Ectomycorrhizal system irregular to monopodial pinnate or monopodial pyramidal; up to 1.8 $\mathrm{cm}$ long; tips $0.2-1 \mathrm{~cm}$ long and up to $1.2-1.7 \mathrm{~mm}$ wide, apex $0.2 \mathrm{~mm}$ wide, base up to $0.23 \mathrm{~mm}$ wide; tips yellowish brown (5YR5/10) to dark brown $(2.5 \mathrm{YR} 2 / 4)$ or black at maturity; unramified ends straight to curved; mantle pale yellow (10YR8/8); soil particles adherent to the mantle surface; host tissue visible under the mantle surface. Rhizomorphs infrequent, pale yellow (5YR7/10) to hyaline. Emanating hyphae frequent, branched, pale yellow (5YR7/10) to hyaline.

Mantle plectenchymatous in all layers (mantle type E, Agerer 1987-2002; Agerer and Rambold 1998), non-gelatinous, hyphae thin long, branched, septate, septa infrequent, hyphae membranaceously and plasmatically pale yellow hyaline, up to $2.3 \mu \mathrm{m}$ wide, contents clear. Emanating hyphae straight, elongated, cylindrical, infrequently septate, $2.7 \mu \mathrm{m}$ in diameter, clamp connections absent, surface smooth, contents clear, ramification frequent, Y-shaped; hyphal endings simple, anastomosing without septum. Cystidia infrequent, lageniform, up to $12.3 \mu \mathrm{m}$ in length, inflated base, up to $4.79 \mu \mathrm{m}$ wide, a long straight neck $1.8 \mu \mathrm{m}$ in diameter. Rhizomorphs hyphae branched, uniform and loosely arranged, intermingled, $2.3 \mu \mathrm{m}$ in diameter, septate, clamp connections not observed, pale yellow to transparent.

Material examined - Pakistan, Khyber Pakhtunkhwa province, Malakand division, Swat district, Kalam, $2400 \mathrm{~m}$ asl, associated with Cedrus deodara, 24 Aug 2014, S. Jabeen \& A. R. Niazi KF6b2; SA217 (LAH-EM47-2013; GenBank KT953617).

\section{Discussion}

Russula brunneopurpurea sp. nov. is characterized by 3 to $7 \mathrm{~cm}$ wide pileus varies in color between purple to brownish purple shades often darker from the centre with some cream tinge at 
the centre or towards the edges, off-white or yellowish hymenium turning ocher with age. A clavate white to yellowish and hollow stipe. Microscopically, it is characterized by its subglobose amyloid basidiospores with sharp-prickly and isolated warts and fusiform, mucronate to rostrate hymenal cystidia and subulate pileocystidia.

The taxon is morphologically similar to $R$. amethystina, $R$. turci Bres. and allies. It is very hard to distinguish these taxa only on the basis of macro-morphological features . Anatomically, $R$. purpurea differs from $R$. amethystina and $R$. amethystina sub sp. tengii, a newly reported species hardly distinguishable from $R$. amethystina from China, in having subulate pileocystidia while both these taxa lack pileocystidia and bear pileipellis with primodial hyphae (Romagnesi 1967b, Sarnari 2005, Li et al. 2016). Russula brunneopurpurea is also distinct from $R$. turci in showing its discoloration of pileus surface from violet to yellowish or off-white on exposure to rain as that of in $R$. amethystina. Russula turci does not show these discolorations. Microscopically $R$. turci bears basidiospores with pronounced mesh pattern between the warts (Michael et al. 1983). ITS sequence comparisons separate all these taxa into distinct clades within the same section.

Ectomycorrhiza of Russula brunneopurpurea is characterized by its irregular to monopodial pinnate or monopodial pyramidal morphotypes and plectenchymatous mantle in all layers. Outer mantle layer bear lageniform cystidia which are typical of Russula ectomycorrhizae. Its ectomycorrhiza can be distinguished from ectomycorrhiza of $R$. anthracina Romagn. that bears pseudoparenchymatous mantle and clamp connections in the emanating hyphae (Jabeen et al. 2016). It is also distinct from ectomycorrhiza of $R$. livescens (Batsch) Bataille forming dichotomous to coralloid morphotypes and a pseudoperenchymatous mantle along with clamped septa in emanating hyphae (Jabeen et al. 2015). Ectomycorrhiza of $R$. brunneopurpurea also differs from ectomycorrhiza of $R$. sichuanensis G.J. Li \& H.A. Wen (Saba \& Khalid 2015) which is dichotomous reported in association with Pinus wallichiana A. B. Jacks. Although the morphotype pattern does not depend merely on the fungus but also the host. So, the morphological characters are not sufficient to identify the fungal component in ectomycorrhizal system. Sequence generated from ectomycorrhizal tissue clustered at the same position with sequences generated from basidiomata of $R$. brunneopurpurea in phylogenetic tree confirmed its identity.

Russula brunneopurpurea was found from dry temperate coniferous forests dominated by Cedrus deodara on loamy soil with low $p \mathrm{H}$. Its ectomycorrhiza is being reported in association with $C$. deodara. A sequence generated from root tip of Pinus wallichina submitted to GenBank as $R$. lutea (KF679818) from Pakistan also clustered with the $R$. brunneopurpurea sequences generated during this study, thus confirming its identity. 


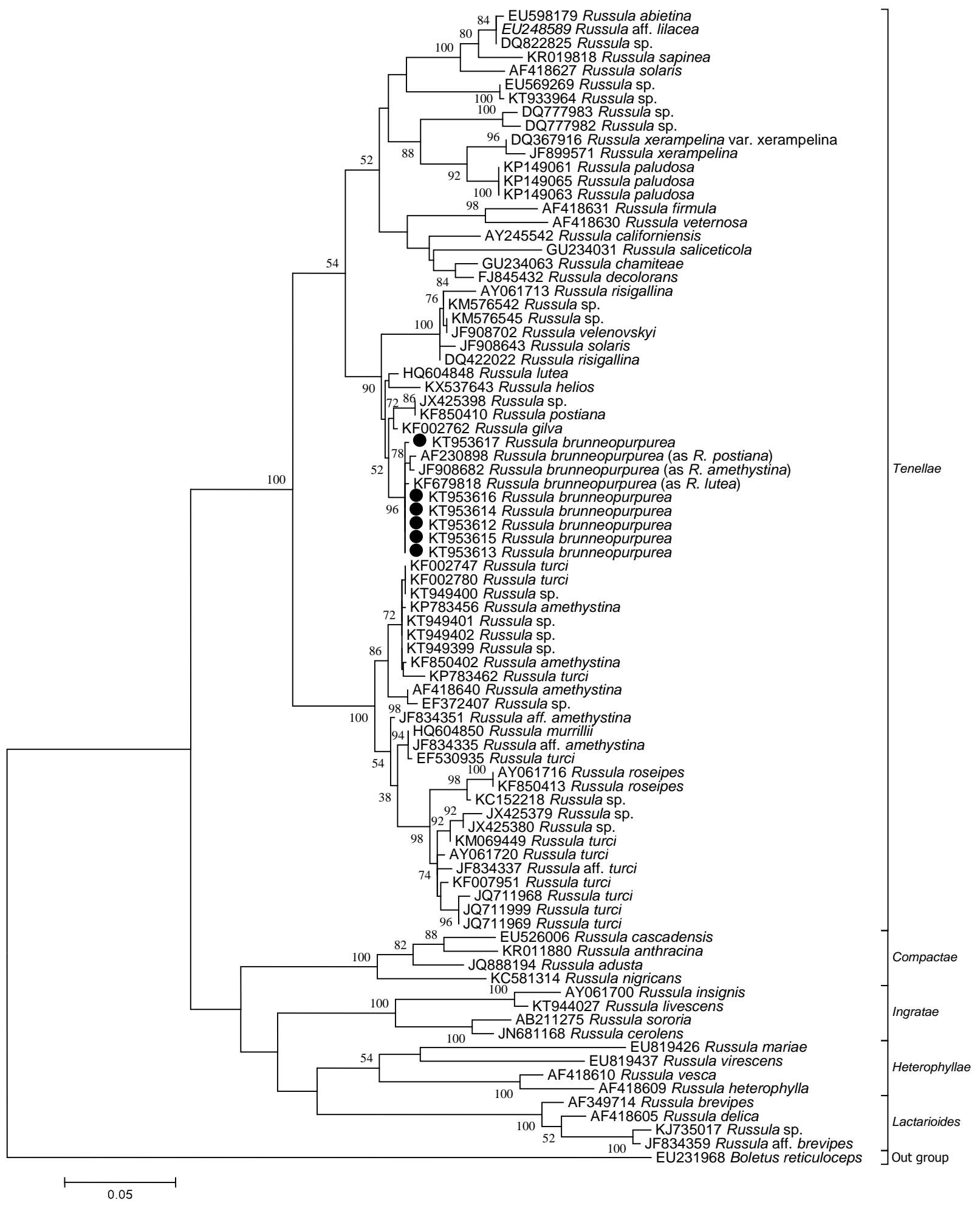

Figure 1 - Molecular phylogenetic analysis of Russula brunneopurpurea based on ITS sequences. The evolutionary history was inferred by the Maximum Likelihood method. The analysis involved 84 nucleotide sequences. There were a total of 816 positions in the final dataset. Sequences generated during this study are marked with 


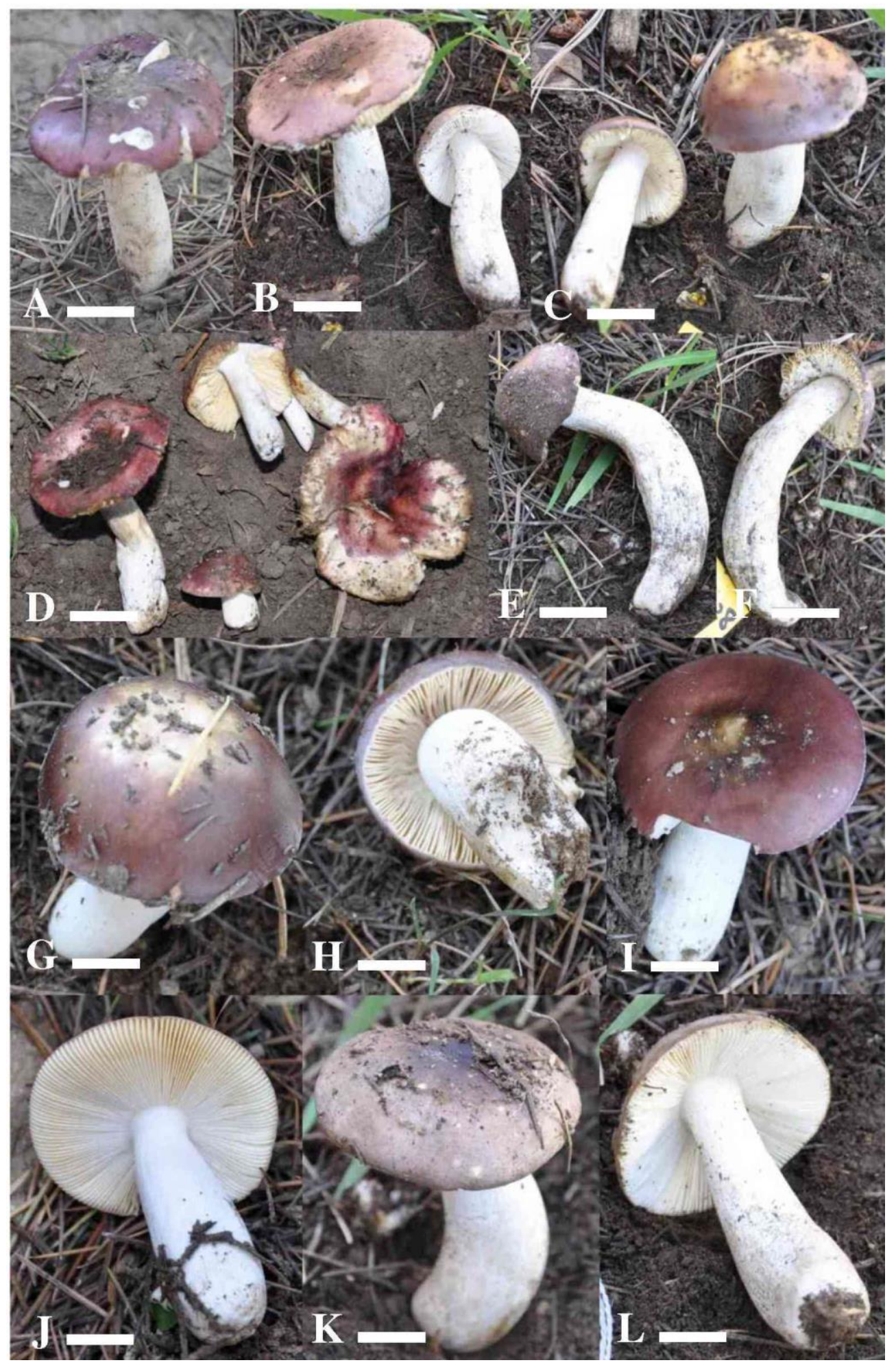

Figure 2 - Morphology of Russula brunneopurpurea. A-L. Basidiomata. A. LAH35058 (Holotype); B. LAH35059; C. LAH35060; D. LAH35057; E and F. LAH35061; G and H. LAH35063; I and J. LAH35064; K and L. LAH35062. Bars: A-L = $1.3 \mathrm{~cm}$. Photographs by Sana Jabeen and Abdul Nasir Khalid 


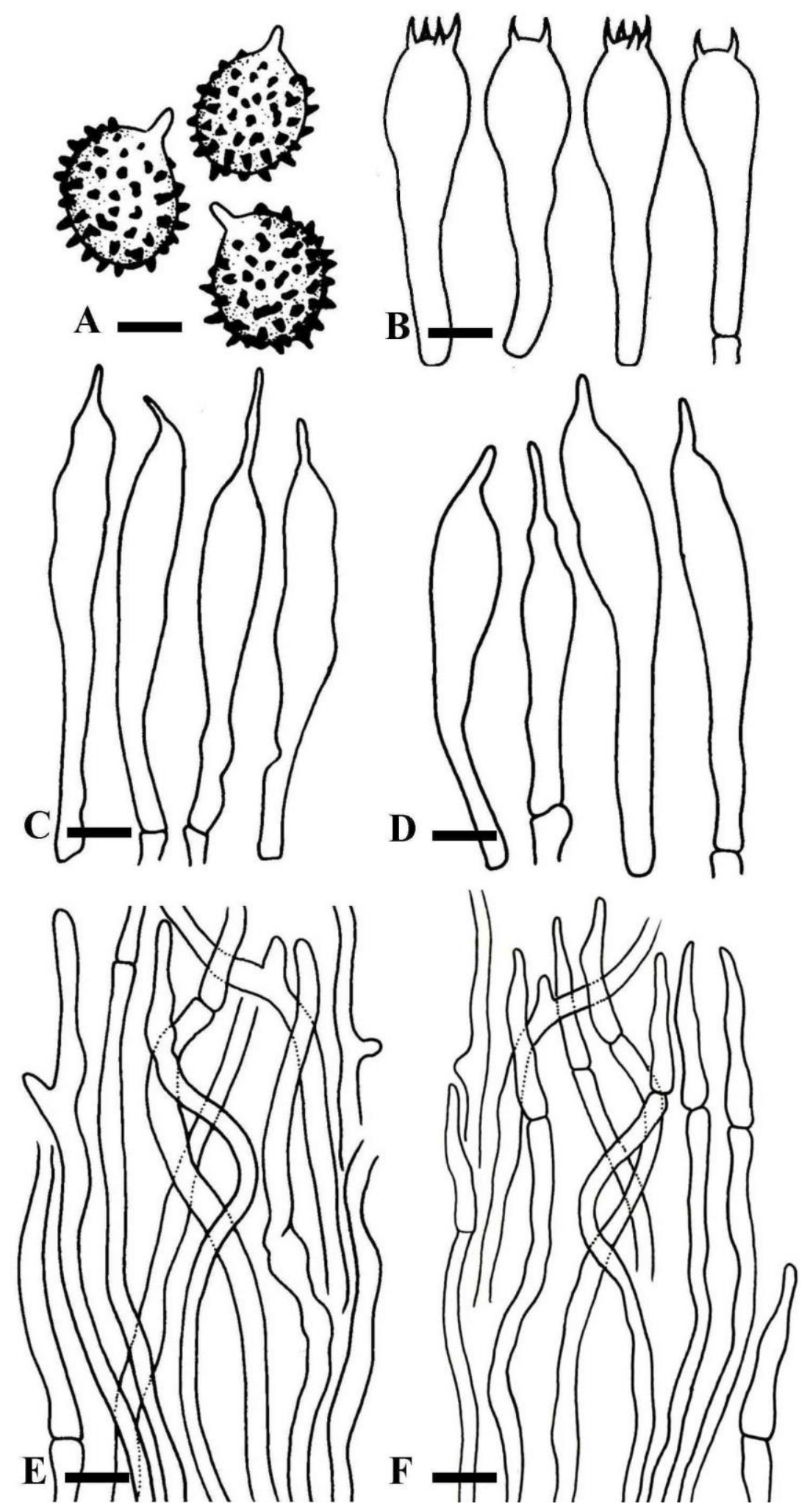

Figure 3 - Anatomy of Russula brunneopurpurea. A-F. LAH35058. A. Basidiospores; B. Basidia; C. Pleurocystidia; D. Cheilocystidia; E. Stipitipellis; F. Pileipellis with pileocystidia. Bars: $\mathrm{A}=5.4 \mu \mathrm{m} ; \mathrm{B}=11 \mu \mathrm{m}, \mathrm{C}=12.3 \mu \mathrm{m} ; \mathrm{D}=11.2 \mu \mathrm{m} ; \mathrm{E}$ and $\mathrm{F}=21.1 \mu \mathrm{m}$. Drawing by Sana Jabeen. 

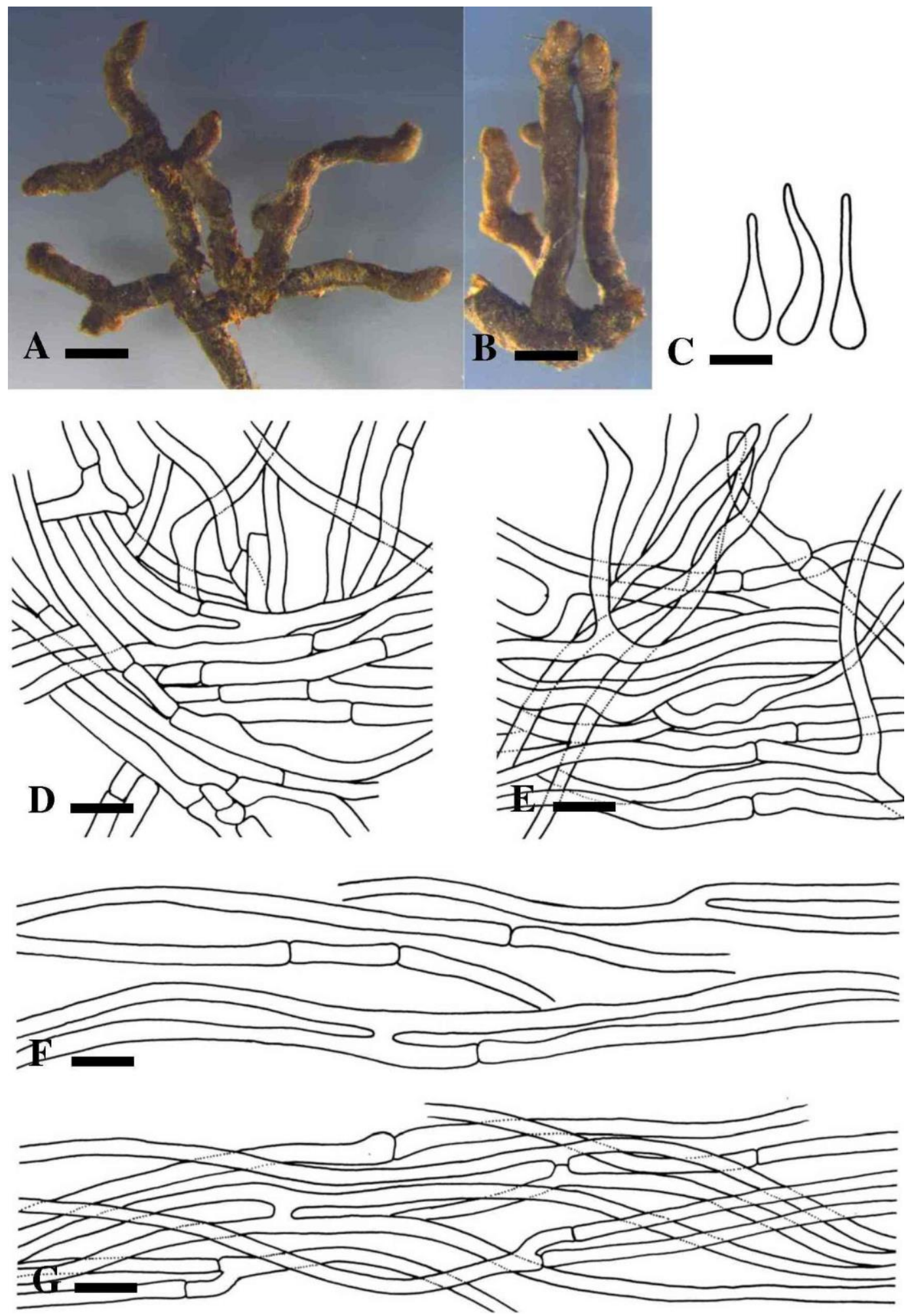

Figure 4 - Ectomycorrhiza of Russula brunneopurpurea. A-G. LAH-EM12-2014. A and B. Ectomycorrhizal morphotypes; C. Cystidia from outer mantle surface; D. Inner mantle layer; E. Outer mantle layer; F. Emanating hyphae; G. Rhizomorphs. Bars: A and B $=0.3 \mathrm{~cm}, \mathrm{C}=4.6 \mu \mathrm{m}$; D and $E=6 \mu \mathrm{m} ; \mathrm{F}=8.1 \mu \mathrm{m} ; \mathrm{G}=7 \mu \mathrm{m}$. Photograph and drawing by Sana Jabeen.

\section{Acknowledgements}

Thanks to Higher Education Commission (HEC), Pakistan for financial assistance under Indigenous Ph. D. Fellowships (Phase II) and International Research Support Initiative Program (IRSIP) to the first author to run Ph. D. project in Pakistan and USA. Thanks to all lab fellows accompanied for the collection. Sincere thanks to Prof. Donald H. Pfister (Harvard University 
Herbaria, Harvard University, MA, USA) for providing the opportunity for the first author to work in his lab. Thanks are also due to Dr. Tine Grebenc (Slovenian Forestry Institute, Department of Forest Physiology and Genetics, Ljubljana, Slovenia) for helpful suggestions to improve the manuscript.

\section{References}

Agerer R, Rambold G. 1998 - DEEMY, a DELTA-based information system for characterization and DEtermination of EctoMYcorrhizae, version 1.1. Section Mycology, Institute for Systematic Botany, University of Munich.

Agerer R. 1991 - Ectomycorrhizae of Sarcodon imbricatus on Norway spruce their chlamydospores. Mycorrhiza 1, 21-30.

Agerer R. 1987-2002 - Colour atlas of ectomycorrhizae. Einhorn-Verlag, Schwäbisch Gmünd.

Ahmad S, Iqbal SH, Khalid AN. 1997 - Fungi of Pakistan. Sultan Ahmad Mycological Society Pakistan, pp. 248.

Bruns TD. 1995 - Thoughts on the processes that maintain local species diversity of ectomycorrhizal fungi. In The significance and regulation of soil biodiversity. Springer Netherlands. pp. 63-73. http://dx.doi.org/10.1007/978-94-011-0479-1_5.

Buyck B, Hofstetter V, Eberhardt U, Verbeken A, Kauff F. 2008 - Walking the thin line between Lactarius and Russula: the dilemma of Russula sect. Ochricompactae. Fungal Diversity 28, $15-40$.

Buyck B, Hofstetter V, Verbeken A, Walleyn R. 2010 - Proposal1919: To conserve Lactarius nom. cons. (Basidiomycota) with a conserved type. Mycotaxon 111, 504-508.

Champion HG, Seth SK, Khattak GM. 1965 - Forest types of Pakistan. Pakistan Forest Institute, Peshawar, Pakistan, p. 238.

Das K, Dowie NJ, Li GJ, Miller SL. 2014 - Two new species of Russula (Russulales) from India. Mycosphere 5, 612-622.

Das K, Sharma JR, Atri NS. 2006 - Russula in Himalaya 3: a new species of subgenus Ingratula. Mycotaxon 95, 271-275.

Das K, Van de PK, Buyck B. 2010 - New or interesting Russula from Sikkim Himalaya (India). Cryptogamie Mycologie 31, 1-15.

Dutta AK, Paloi S, Pradhan P, Acharya K. 2015 - A new species of Russula (Russulaceae) from India based on morphological and molecular (ITS sequence) data. Turkish Journal of Botany 39, 850-856. http://dx.doi.org/10.3906/bot-1407-1.

Gardes M, Bruns TD. 1993 - ITS primers with enhanced specificity for basidiomycetes application to the identification of mycorrhizae and rusts. Molecular Ecology 2, 113-118. http://dx.doi.org/10.1111/j.1365-294X.1993.tb00005.x.

Ge ZW, Yang ZL, Vellinga EC. 2010 - The genus Macrolepiota (Agaricaceae, Basidiomycota) in China. Fungal Diversity 45, 81-98. http://dx.doi.org/10.1007/s13225-010-0062-0.

Hall TA. 1999 - BioEdit: a user-friendly biological sequence alignment editor and analysis program for Windows 95/98/NT. Nucleic Acids Symposium Series 41, 95-98.

Hamayun M. 2003 - Ethnobotanical studies of some useful shrubs and trees of District Buner, NWFP, Pakistan. Journal of Ethnobotanical Leaflets (http://www.siu.edu/ ebl/).

Jabeen S, Fiaz M, Saba M, Habib A, Khalid AN. 2015 - Molecular phylogeny and morphological characterization of Russula livescens and its ectomycorrhiza from mixed coniferous forests of Pakistan. Austrian Journal of Mycology 24, 143-152.

Jabeen S, Niazi AR, Khalid AN. 2016 - First record of Russula anthracina and its ectomycorrhiza associated with Himalayan cedar from South Asia. Mycotaxon 131, 31-44. http://dx.doi.org/10.5248/131.31.

Jukes TH, Cantor CR. 1969 - Evolution of protein molecules. In Munro HN, editor, Mammalian Protein Metabolism, Academic Press, New York, pp. 21-132. 
Khatua S, Dutta AK, Acharya K. 2015 - Prospecting Russula senecis: a delicacy among the tribes of West Bengal. Peer J, 3, e810. http://dx.doi.org/10.7717/peerj.810.

Larsson E, Larsson KH. 2003 - Phylogenetic relationships of russuloid basidiomycetes with emphasis on aphyllophoralean taxa. Mycologia 95, 1037-1065. http://dx.doi.org/10.2307/3761912.

Li GJ, Zhao D, Li SF, Wen HA. 2015 - Russula chiui and R. pseudopectinatoides, two new species from south western China supported by morphological and molecular evidence. Mycological Progress 14, 33. http://dx.doi.org/10.1007/s11557-015-1069-4.

Li GJ, Hyde KD, Zhao RN, Hongsanan S, Abdel-Aziz FA, Abdel-Wahab MA,..., Maharachchikumbura SSN. 2016 - Fungal diversity notes 253-366: taxonomic and phylogenetic contributions to fungal taxa. Fungal Diversity 78, 1-237.

Li GJ, Zhao Q, Zhao D, Yue SF, Li SF, Wen HA, Liu XZ. 2013 - Russula atroaeruginea and $R$. sichuanensis spp. nov. from southwest China. Mycotaxon 124, 137-188. http://dx.doi.org/10.5248/124.173.

Manimohan P, Latha KPD. 2011 - Observation on two rarely collected species of Russula. Mycotaxon 116, 125-131. http://dx.doi.org/10.5248/116.125.

Michael E, Hennig B, Kreisel H. 1983 - Handbook for fungal friends. Fifth Volume: agarics Milkcaps and Russulas.2 Edition. Fischer, Stuttgart, p. 306.

Miller SL, Buyck B.2002 - Molecular phylogeny of the genus Russula in Europe with a comparison of modern infrageneric classifications. Mycological Research 106, 259-276. http://dx.doi.org/10.1017/S0953756202005610

Munsell Soil Color Charts. 1975 - Munsell Color Co., Baltimore, M. D.

Nei M, Kumar S. 2000 - Molecular Evolution and Phylogenetics. Oxford University Press, New York

Niazi AR. 2008 - Biodiversity of ectomycorrhizas in conifers from Himalayan moist temperate forests of Pakistan. Ph. D. dissertation, Department of Botany, University of the Punjab, Lahore, Pakistan.

Niazi AR, Iqbal SH, Khalid AN. 2006 - Biodiversity of mushrooms and ectomycorrhiza. 1. Russula brevipes Peck. and its ectomycorrhiza, a new record from Himalayan moist temperate forests of Pakistan. Pakistan Journal of Botany 38, 1271-1277.

Paloi S, Dutta AK, Acharya K. 2015 - A new species of Russula (Russulales) from Eastern Himalaya, India. Phytotaxa 234, 255-262. http://dx.doi.org/10.11646/phytotaxa.234.3.6

Park MS, Lee H, Oh SY, Jung PE, Seok SJ, Fong JJ, Lim YW. 2014 - Species delimitation of three species within the Russula subgenus Compacta in Korea: $R$. eccentrica, $R$. nigricans, and $R$. subnigricans. Journal of Microbiology, 52, 631-638. http://dx.doi.org/10.1007/s12275-0144168-z.

Razaq A, Ilyas S, Khalid AN, Niazi AR. 2014 - Russula foetentoides sp. nov. (Russulales, Russulaceae)-a new species from Pakistan. Sydowia 66, 289-298.

Romagnesi H. 1967a - Russules d'Europe et d'Afique du Nord. Bordas, Paris Romagnesi H (1985) Les Russules d' Europe et d' Afrique du Nord. Reprint with supplement. J. Cramer, Lehre.

Romagnesi H. 1967b - Russula amethystina Les Russules d'Europe et d'Afrique du Nord. In: mycobank.org The Fungal site. Accessed on16th August 2011 (French).

Romagnesi H. 1985 - Les Russules d' Europe et d'Afrique du Nord. Reprint with supplement. J. Cramer, Lehre.

Saba M, Khalid AN. 2015 - Russula sichuanensis and its ectomycorrhizae from Himalayan moist temperate forests of Pakistan. Mycotaxon, 130, 629-639. http://dx.doi.org/10.5248/130.629.

Sarnari M. 2005 - Monografia illustrate de genere Russula in Europa. Tomo Secondo. AMB, Centro Studi Micologici, Trento.

Shimono Y, Kato M, Takamatsu S. 2004 - Molecular phylogeny of Russulaceae (Basidiomycetes; Russulales) inferred from the nucleotide sequences of nuclear large subunit rDNA. Mycoscience 45, 303-316. http://dx.doi.org/10.1007/S10267-004-0189-5. 
Stucki B, Khan HA. 1999 - Working plan for Utror-Desan forests of Kalam Forest Division. Nizam Printing Press, Peshawar.

Tamura K, Stecher G, Peterson D, Filipski A, Kumar S. 2013 - MEGA6: Molecular Evolutionary Genetics Analysis version 6.0. Molecular Biology and Evolution 30, 2725-2729. http://dx.doi.org/10.1093/molbev/mst197.

White TJ, Bruns TD, Taylor LJ. 1990 - Amplification direct sequencing of fungal ribosomal RNA genes for Phylogenetics. In: Innis, MA, Gelf DH, Sninsky JJ, White TJ (eds.). PCR protocols:A guide to methods applications. Academic Press, New York, pp. 315-322. http://dx.doi.org/10.1016/b978-0-12-372180-8.50042-1.

Zhao Q, Li YK, ZHu XT, Zhao YC, Liang JF. 2015 - Russula nigrovirens sp. nov. (Russulaceae) from

southwestern

China. Phytotaxa,

236 ,

249-256.

http://dx.doi.org/10.11646/phytotaxa.236.3.5. 